\title{
Physicochemical characterization of wines obtained of cultivar Isabel (hybrid of Vitis vinifera x Vitis labrusca) from different Brazilian states
}

\author{
Marcio Paulo Czepak ${ }^{1, a}$, Amanda Costa $^{1}$, Giuliano Elias Pereira ${ }^{2}$, Reginaldo Teodoro de Souza ${ }^{3}$, Lucas Caetano \\ Gonçalves $^{1}$, and Edilson Romais Schmildt ${ }^{1}$ \\ ${ }^{1}$ Universidade Federal do Espírito Santo, 29.932-540, São Mateus ES, Brasil \\ ${ }^{2}$ Embrapa Semi-Árido, 56.302-970, Petrolina PE, Brasil \\ ${ }^{3}$ Embrapa Uva e Vinho, 15.700-000, Jales SP, Brasil
}

\begin{abstract}
The cultivar of hybrid grape Isabel (Vitis vinifera $\times$ Vitis labrusca) is one of the main raw materials for table wine preparation in Brazil. It is be very adapted to the environmental conditions, has a high productivity capacity and low susceptibility to major fungal diseases that attack the vine. Wines made from grapes of the Vitis labrusca species and hybrids have the preference of the majority of Brazilian consumers and a considerable market. Although imparts "foxiness" for wine and therefore receive many objections of winemakers, this wine is gaining the characteristics of each region where it is produced. This study aimed to characterize the wines produced with the cultivar Isabel four states of Brazil. The experimental design was in split plots and plots were the states (ES, PE, RS and MG) and the subplots were the vintages (2014-2015), the treatments consisted of 3 repetitions each. The variables analyzed were: alcohol $\left({ }^{\circ} \mathrm{GL}\right)$ and total volatile acidity $\left(\mathrm{g} \mathrm{L}^{-1}\right)$, dry extract $\left(\mathrm{g} \mathrm{L}^{-1}\right)$, free and total $\mathrm{SO}_{2}$, color index, the tone $(420 \mathrm{~nm}+520 \mathrm{~nm})$, polyphenols, anthocyanins content $\left(\mathrm{mg} \mathrm{L}^{-1}\right)$, phenolic compounds $\left(\mathrm{m} \mathrm{L}^{-1}\right)$ and organic acids. The state of MG vintages 2014 and 2015, received the highest averages in the most of the variables analyzed.
\end{abstract}

\section{Introduction}

Among the grapes, the cultivar Isabel is one of the main raw materials for the preparation of table wine in Brazil. This is better adapted to environmental conditions and a high production and low susceptibility to major fungal diseases that attack the vine. The wines produced with V. labrusca grapes are differentiated from fine wines by their aroma and flavor. Specific molecules, such as methyl anthranilate, and the oaminoacetofenona 2.5-dimethyl4-hydroxy-Furan-3-one (furaneol) are responsible for specific aromas typical of these varieties, and these characteristics are preferred for many Brazilian consumers, there is considerable market enjoying wine made from these grapes $[1,2]$.

The Brazilian wine is distinguished from other markets by the particularity of the acceptance of products originating in the American varieties (Vitis labrusca) and hybrid, unlike the foreign market in which only products originating in the European varieties (Vitis vinifera L.) are accepted [3]. The main tropical viticulture centers in Brazil are the Vale do São Francisco, the northwest of São Paulo state and the north of Minas Gerais state. In recent years, the tropical viticulture has expanded throughout several other states, as Espírito Santo, Mato Grosso do Sul, Mato Grosso, Goiás, Rondônia, Ceará and Piauí [3]. The objective of this work is demonstrate the different characteristics of red wine $\mathrm{cv}$. Isabel of each region studied (Espírito Santo, Minas Gerais, Pernambuco and
Rio Grande do Sul state), and the different characteristics between vintage 2014/2015 for each state.

\section{Material and methods}

The wine samples produced with the cultivar Isabel (V. labrusca), vintages 2014 and 2015 were from states of Pernambuco, Rio Grande do Sul, Espírito Santo and Minas Gerais, being designated as PE samples, RS, ES and MG respectively. All samples are commercial and were collected at random, and the same batch manufacturing process. Samples were identified as follows: Pernambuco (vintage PE 2014 / PE vintage 2015), Rio Grande do Sul (RS vintage 2014 / RS vintage 2015), Espírito Santo (ES vintage 2014 / ES vintage 2015), and Minas Gerais (MG vintage 2014 / MG vintage 2015). The chemical analyses were performed in triplicate ( 3 bottles) and held in oenology laboratory of Embrapa Semi-Arid located in Petrolina-PE, Brazil.

The microvinification was conducted in oenology laboratory of Universidade Federal do Espírito Santo (UFES), and the first phase for microvinification was the harvest of grapes (cv. Isabel), in June of 2015, in the city of Mountain - ES, which has an altitude of 180 meters, and is located at latitude $18^{\circ} 07^{\prime} 33$ "S and longitude $40{ }^{\circ} 21^{\prime} 46^{\prime \prime} \mathrm{W}$. The harvest was done according to the grapes ripening and transportation was carried out in $20 \mathrm{~kg}$ boxes. Initially, the cleaning of the bunches was done by washing them with a solution of water and sodium hypochlorite and rinsed with pure water. Soon afterwards, 
the berries were separated from the rachis, and smashed up. The mash was placed into $20 \mathrm{~L}$ acrylic carboy, adapted to brew valve (airlock) and fermented in a room with a temperature of 23 to $25^{\circ} \mathrm{C}$. Each container had a total of $15 \mathrm{~kg}$ of grapes.

The fermentation period was 10 days, with two daily remounting. After this time, racking was made (separation of solid and liquid part of the must). The racking occurred 15,30 and 45 days after racking, where, in the end, another dose of potassium metabisulfite $\mathrm{K}_{2} \mathrm{~S}_{2} \mathrm{O}_{5}\left(0.33 \mathrm{~g} \mathrm{~L}^{-1}\right)$ was added. The stabilization was done during 10 days and after this period the wine was filtered and bottled. With $15 \mathrm{~L}$ of must was generated $10 \mathrm{~L}$ of wine. The chemical analyzes were performed in triplicate ( 3 bottles) and held in oenology laboratory of Embrapa Semi-Arid, located in Petrolina-PE.

\subsection{Relative density, alcohol content ( $\left.{ }^{\circ} \mathrm{GL}\right)$, and dry extract $\left(\mathrm{g} \mathrm{L}^{-1}\right)$}

The relative density, alcohol content $\left({ }^{\circ} \mathrm{GL}\right)$, and dry extract $\left(\mathrm{gL}^{-1}\right)$ were determined through analyses adapted by the enology laboratory of Embrapa Semi-Arid, based on the analysis described by AOAC (1998) and Ministério da Agricultura, Pecuária e Abastecimento - MAPA [4]. To determine the density hydrostatic balance (Gilbertini model Super Alcomat) was used, obtaining the value of the parameter from the reading $80 \mathrm{~mL}$ of each sample with the temperature at $20^{\circ} \mathrm{C}$. The alcohol content of the wines was determined after the distillation of wine by drag steam distiller in Super DEE (Gilbertini R). To this, $100 \mathrm{~mL}$ of sample, $10 \mathrm{~mL}$ of calcium oxide and $12 \%$ and 3 drops of antifoam agent in a volumetric flask were added. After cooling the distillate obtained from each sample, we proceeded to the measurement of alcohol content from the reading thereof in hydrostatic balance (Gilbertini $\mathrm{R}$ ), a temperature of $20^{\circ} \mathrm{C}$ and the result was obtained by scanning $100 \mathrm{ml}$ of the sample and expressed in $\% \mathrm{~V} / \mathrm{V}$ [5].

The dry extract was determined by the difference between the reading of pure wine sample and reading the dealcoholized sample by steam distillation [5]. For this, we used the reading Module AlcoMat-2 of Hydrostatic balance Densi-Mat, which determines the value of the total dry extract of wines or musts with a density between 0.990 and 1.160 at a temperature between 15 and $25^{\circ} \mathrm{C}_{\text {in }} \mathrm{g} \mathrm{L}^{-1}$.

\section{2. $\mathrm{pH}$}

The $\mathrm{pH}$ (potential of Hydrogen), was measured with the aid of $\mathrm{pH}$ meter (Tecnal, Tec model-3MP), previously calibrated with $\mathrm{pH} 4.00$ buffer solution $\mathrm{pH} 7.00$ and temperature $20^{\circ} \mathrm{C}$.

\subsection{Volatile acidity}

For the determination of volatile acidity, the methodology adapted from the Ministério da Agricultura, Pecuária e Abastecimento - MAPA, according: Métodos de Análises de Bebidas e Vinagres [4] and procedures of the OIV were used. $20 \mathrm{~mL}$ of wine sample was distilled with the Oenochemical Distilling Electronic Unit (Gilbertini model Super DEE) until $240 \mathrm{ml}$ of distillate, with $100 \mathrm{ml}$ of distillate titrated with $0.1 \mathrm{~N} \mathrm{NaOH}$ and phenolphthalein indicator and the remainder was used to corrections, titrating the same with $0.02 \mathrm{~N}$ iodine and starch indicator to discount the free $\mathrm{SO}_{2}$ and total. The volatile acidity was calculated and corrected in grams per liter expressed as acetic acid.

$$
\operatorname{VAC}\left(\mathrm{g} \cdot \mathrm{L}^{-1}\right)=\{[10 .(\mathrm{n} 1-(\mathrm{n} 2.0 .1)-(\mathrm{n} 3.0 .005)] \cdot 006\}
$$

where:

VAC: Volatile acidity corrected;

$\mathrm{N} 1$ : volume in $\mathrm{mL}$ of sodium hydroxide used in the first titration;

$\mathrm{N} 2$ : Volume in $\mathrm{mL}$ of iodine used in the second degree; $\mathrm{N} 3$ : Volume in $\mathrm{ml}$ of iodine used in the third degree.

\subsection{Total acidity}

The determination of the total acidity of the wine was performed using the methodology of [4], which is the titration of the acid with a standardized solution of sodium hydroxide $0.1 \mathrm{~N}$ to reach $\mathrm{pH} 8.2$, at which point occurs the neutralization of acids. Aliquots of $5 \mathrm{~mL}$ of wine were diluted in $50 \mathrm{~mL}$ of deionized water for analysis. A mini magnetic stirrer (Tecnal, TE-0853 model) and $\mathrm{pH}$ meter (Tecnal, Tec-3MP model) previously calibrated according to manufacturer's recommendations were used.

$$
\text { Total acidity }\left(\mathrm{g} \mathrm{L}^{-1}\right)=\mathrm{V}_{\mathrm{NaOH}} \cdot 1.5 \text {. }
$$

\subsection{Free and total sulfur dioxide}

For the determination of free sulfur dioxide was added to $25 \mathrm{~mL}$ of sample, $2.5 \mathrm{~mL}$ of sulfuric acid 1:3(v:v) and $2 \mathrm{~mL}$ of $1 \%$ starch solution (indicator) was titrated with Solution $0.02 \mathrm{~N}$ iodine to the turning point. The determination of total sulfur dioxide was done by pipetting up $25 \mathrm{~mL}$ of the sample, adding $12.5 \mathrm{~mL}$ of sodium hydroxide $1 \mathrm{~N}$ and leaving at rest for 15 minutes. After this time was added $5 \mathrm{~mL}$ of sulfuric acid 1:3 (v:v) (diluted in distilled water) starch solution and $2 \mathrm{~mL}$ of $1 \%$ and titrating with $0.02 \mathrm{~N}$ iodine solution to the turning point. To determine the total or free sulfur dioxide concentration $\left(\mathrm{mg} \mathrm{L}^{-1}\right)$ present in the samples was the calculation by the equation:

$$
\mathrm{SO}_{2 \text { free or total }}\left(\mathrm{mg} \mathrm{L}^{-1}\right)=\mathrm{V}_{\text {used }} \cdot \mathrm{N} \cdot \mathrm{fc} \cdot 32 \cdot 100 / \mathrm{V}_{\text {sample }}
$$

where:

$\mathrm{V}_{\text {used }}$ - volume in $\mathrm{mL}$ of iodine solution used in titration; $\mathrm{N}$ : Normality of the iodine solution $(0.02 \mathrm{~N})$;

Fc: correction factor of iodine solution;

$\mathrm{V}_{\text {sample }}$ : Sample volume used $(1 \mathrm{~mL})$.

\subsection{Total polyphenols index (TPI)}

The total polyphenol content is characterized by measuring the absorbance of the blue color of the benzene cycles the majority of tannins by spectrophotometer [6]. To measure the TPI diluted wine 1:100 with distilled water and held reading the absorbance at $280 \mathrm{~nm}$ in a quartz cuvette of $10 \mathrm{~mm}$ optical path in a spectrophotometer UV/VIS, wherein the polyphenol content was the expression calculated as follows:

TPI $(\mathrm{I} 280 \mathrm{~nm})=$ Reading $\times$ dilution. 


\subsection{Total monomeric anthocyanins}

The methodology used in the determination of total anthocyanins in wines was the $\mathrm{pH}$ difference. Two buffer solutions were prepared, a $0.025 \mathrm{M}$ potassium chloride P.A with hydrochloric acid until the $\mathrm{pH}$ reach 1.0, the other sodium acetate added to $0.4 \mathrm{M}$ P.A hydrochloric acid to $\mathrm{pH}$ 4.5. The wine samples were diluted (1/10) with the buffer solutions and the reading was made at $520 \mathrm{~nm}$ and $700 \mathrm{~nm}$, in the buffer $\mathrm{pH} 1.0$ and $\mathrm{pH}$ 4.5. The reading was performed at $700 \mathrm{~nm}$ to discount the turbidity of the sample. The value of the final absorbance $\left(A_{F}\right)$ was calculated from the equation:

$A_{F}=\left(A_{520 \mathrm{~nm}}-A_{700 \mathrm{~nm}}\right)_{\mathrm{pH} .1 .0}-\left(\mathrm{A}_{520 \mathrm{~nm}}-\mathrm{A}_{700 \mathrm{~nm}}\right)_{\mathrm{pH} 4.5}$.

The pigment concentration in the sample was calculated and represented as cyanidin-3-glucoside, according to the equation:

$$
\operatorname{Anthocyanin}\left(\mathrm{mg} \mathrm{L}^{-1}\right)=\left(\mathrm{A}_{\mathrm{F}} \cdot \mathrm{PM} \cdot \mathrm{FD} \cdot 1000\right) /(\varepsilon \cdot 1)
$$

where:

$\mathrm{PM}=$ anthocyanin molecular weight (449.2);

$\mathrm{DF}=$ dilution factor (10);

$\varepsilon=$ molar absorptivity of cyanidin 3-glucoside (26900).

\subsection{Color and tone}

The procedure used for determining the color intensity and hue of the wine was the spectrophotometric method described by Rizzon [1]. To do, a reading the absorbance of the wine samples held was made without dilution after centrifugation for 5 minutes at $3000 \mathrm{rpm}$ by placing an aliquot of each sample in quartz cuvette with $0.5 \mathrm{~cm}$ light path at a wavelength of 420 (detected yellow tones), 520 (detect red tones) and $620 \mathrm{~nm}$ (detects purple tones / lilac) using spectrophotometer Biomol brand, SP-220 model. The result of the wines staining intensity was obtained from the sum of the absorbance of the samples for the three wavelengths and the color tone by the ratio of absorbance at wavelengths of $420 \mathrm{~nm}$ and $520 \mathrm{~nm}$.

\subsection{Chromatography (phenolic compounds)}

Phenolic compounds were determined by HPLC on a chromatograph (Alliance e2695 model) equipped with quaternary solvent pump and autosampler coupled with DAD and fluorescence detection (FD), according to the methodology described by Natividadeet et al [7]. The data collection and analysis were performed using the Empower ${ }^{\mathrm{TM}} 2$ software (Milford, USA). In the DAD detection of compounds was performed at $280 \mathrm{~nm}$ for gallic acid, gallate epiacatequina and epigalatocatequina gallate; $360 \mathrm{~nm}$ for kaempferol-3O-glucoside, isorhamnetin-3-O-glucoside, kaempferol-3O-glucoside, quercetin piranosídeo, quercetin, cutin; $520 \mathrm{~nm}$ for Pelargonidin-3-O-glucoside, malvidin 3.5-di-O-glucoside, petunidin 3-O-glucoside, malvidin-3$\mathrm{O}$-glucoside, peonidin-3-O-glucoside, petunidin 3-Oglucoside clorídeo, cyanidin-3.5-di-O-glucoside, cyanidin3-O-glucoside; $320 \mathrm{~nm}$ for caffeic acid, cinnamic acid, chlorogenic acid, p-coumaric acid, trans-resveratrol; and fluorescence with excitation at $280 \mathrm{~nm}$ and emission at $320 \mathrm{~nm}$ for catechin, epicatechin, procyanidin A2, procyanidin B1, procyanidin B2.
The limit of detection ranged from 0.001 to $0.19 \mathrm{mg} \mathrm{L} \mathrm{L}^{-1}$ and $\mathrm{R}^{2}$ was always greater than 0.983 for all compounds tested. The column used was a Gemini-NX C18, $150 \times 4.60 \mathrm{~mm}, 3 \mu \mathrm{m}$ particle inside, and pre-Gemini-NX C18 column, $4.0 \times 3.0 \mathrm{~mm}$, both manufactured by Phenomenex. The oven temperature was maintained at $40^{\circ} \mathrm{C}$, injection volume was $10 \mathrm{uL}$ (wine previously filtered through a $0.45 \mathrm{uM}$ membrane; Allcrom Phenomenex, USA) and the flow rate was $0.5 \mathrm{~mL} \mathrm{~min}^{-1}$. The gradient used for the separation is $0 \mathrm{~min}$ : $100 \% \mathrm{~A}$; $10 \mathrm{~min}: 93 \% \mathrm{~A}$ and $\% \mathrm{~B} 7 ; 20 \mathrm{~min}: 90 \% \mathrm{~A}$ and $10 \% \mathrm{~B}$; $30 \mathrm{~min}$ : $88 \% \mathrm{~A}$ and $12 \% \mathrm{~B}$; $40 \mathrm{~min}: 77 \% \mathrm{~A}$ and $33 \% \mathrm{~B}$; 45 min: $65 \%$ A and $35 \%$ B, 55 min: $100 \%$ B, where solvent $\mathrm{A}$ is a phosphoric acid solution and $0.85 \%$ solvent $\mathrm{B}$ is acetonitrile.

\subsection{Chromatography (organic acids)}

Quantitation of tartaric, malic, citric, lactic, succinic, acetic acid was performed using chromatograph (model Alliance e2695) coupled with a diode array detector (DAD), following the methodology described by Rybka et al [8]. The samples were filtered through a $0.45 \mathrm{uM}$ membrane and injected in triplicate. The wavelength of $210 \mathrm{~nm}$ was maintained for tartaric, malic, citric, lactic, succinic and acetic acid, with a $15 \mathrm{~min}$ run time, and flow rate of $0.6 \mathrm{~mL} \mathrm{~min} \mathrm{~m}^{-1}$ at $26^{\circ} \mathrm{C}$ and injection volume of $10 \mathrm{uL}$. The column used was a Gemini-NX C18 column $(150 \times$ $4.60 \mathrm{~mm}$, with internal particles $3 \mathrm{mM}$ ) and the guard column was a Gemini-NX C18 column $(4.0 \times 3.0 \mathrm{~mm})$ both manufactured by Phenomenex ${ }^{\circledR}$. The liquid phase was composed of a $0.025 \mathrm{M}$ solution of $\mathrm{KH}_{2} \mathrm{PO}_{4}$ acidified with $\mathrm{H}_{3} \mathrm{PO}_{4}$ to $\mathrm{pH}$ 2.6.

\subsection{Statistics}

Analysis of variance was performed and means were compared by Tukey test ( $p$ 0.01) using the ASSISTAT software, version 7.7 beta [9].

\section{Results and discussion}

When held in wines, the physic-chemical analysis in addition to presenting a legal requirement for marketing guide the control of any fault detection and quality that can occur throughout the production chain [10]. These analyzes also inform important aspects such as color, structure, quality and possible changes caused by microbiological agents or the use of oenological practices and inappropriate products in wines [11].

The Brazilian law establishes the following standards for table wine: alcohol content of $8.6 \%$ to $14 \%$ by volume; maximum total acidity of $130.0 \mathrm{mEq} \mathrm{L} \mathrm{L}^{-1}$, maximum volatile acidity of $20.0 \mathrm{mEq} \mathrm{L}^{-1}$; maximum sulfur dioxide free of $0.35 \mathrm{~g} \mathrm{~L}^{-1}$. For the classification of the total sugar content, dry wine are those with up to $5.0 \mathrm{~g} \mathrm{~L}^{-1}$ sugar; dried through maximum of $20 \mathrm{~g} \mathrm{~L}^{-1}$ and minimum of $5.1 \mathrm{~g} \mathrm{~L}^{-1}$; and sweet or smooth wines are those with higher levels of $20.1 \mathrm{~g} \mathrm{~L}^{-1}$ [12]. Tables 1, 2 and 3 show the values obtained in enoquímicas analysis, and demonstrate that the wines sold in different study regions are within the standards required by the Brazilian law, compared to the analyzes.

Factors affecting the alcohol content can be divided as those which are not linked to the elaboration of the 
Table 1. Density, alcohol content and dry extract of wine from cv. Isabel produced in different states of Brazil on 2 vintage.

\begin{tabular}{|c|c|c|c|c|c|c|}
\hline \multirow{3}{*}{ States } & \multicolumn{6}{|c|}{ Analysis } \\
\hline & \multicolumn{2}{|c|}{ Density } & \multicolumn{2}{|c|}{$\left({ }^{\circ} \mathrm{GL}\right)$} & \multicolumn{2}{|c|}{ Dry extract $\left(\mathrm{g} \mathrm{L}^{-1}\right)$} \\
\hline & Vint. 2014 & Vint. 2015 & Vint. 2014 & Vint. 2015 & Vint. 2014 & Vint. 2015 \\
\hline $\mathrm{PE}$ & $0.996^{\mathrm{bA}} \pm 0$ & $0.996^{\mathrm{aA}} \pm 0$ & $11.01^{\mathrm{bA}} \pm 0$ & $10.9^{\mathrm{bA}} \pm 0.01$ & $27.16^{\mathrm{bB}} \pm 1.1$ & $28.80^{\mathrm{aA}} \pm 0.08$ \\
\hline RS & $0.996^{\mathrm{aA}} \pm 0$ & $0.9962^{\mathrm{aB}} \pm 0$ & $10.0^{\mathrm{cB}} \pm 0.8$ & $10.3^{\mathrm{cA}} \pm 0$ & $26.53^{\mathrm{bA}} \pm 0.2$ & $26.20^{\mathrm{bA}} \pm 0.4$ \\
\hline ES & $0.995^{\mathrm{bB}} \pm 0$ & $0.9961^{\mathrm{aA}} \pm 0$ & $11.1^{\mathrm{bA}} \pm 0.04$ & $10.4^{\mathrm{cB}} \pm 0.1$ & $27.30^{\mathrm{abA}} \pm 0.1$ & $26.13^{\mathrm{bB}} \pm 0.1$ \\
\hline MG & $0.994^{\mathrm{cB}} \pm 0$ & $0.9955^{\mathrm{bA}} \pm 0$ & $12.2^{\mathrm{aA}} \pm 0.01$ & $11.9^{\mathrm{aB}} \pm 0$ & $28.56^{\mathrm{aA}} \pm 0.1$ & $29.36^{\mathrm{aA}} \pm 0.2$ \\
\hline
\end{tabular}

Means followed by the same letter in the column and capital in line do not differ by $\mathrm{F}$ and Tukey test at $1 \%$ probability of error.

Table 2. Total acidity, volatile acidity, and $\mathrm{pH}$ of wine from cv. Isabel produced in different states of Brazil on 2 vintage.

\begin{tabular}{lcccccc}
\hline \multirow{3}{*}{ States } & \multicolumn{5}{c}{ Analysis } \\
\cline { 2 - 7 } & \multicolumn{2}{c}{ Total acidity $\left(\mathrm{g} \mathrm{L}^{-1}\right)$} & \multicolumn{2}{c}{ Volatile Acidity $\left(\mathrm{g} \mathrm{L}^{-1}\right)$} \\
\cline { 2 - 7 } & Vintage 2014 & Vintage 2015 & Vintage 2014 & Vintage 2015 & Vintage 2014 & Vintage 2015 \\
\hline PE & $7.55^{\mathrm{cB}} \pm 0.1$ & $8.65^{\mathrm{bA}} \pm 0.07$ & $0.72^{\mathrm{cB}} \pm 0.03$ & $0.89^{\mathrm{bA}} \pm 0.02$ & $3.50^{\mathrm{bB}} \pm 0.01$ & $3.67^{\mathrm{aA}} \pm 0$ \\
$\mathrm{RS}$ & $8.45^{\mathrm{bB}} \pm 0.14$ & $9.0^{\mathrm{bA}} \pm 0.5$ & $0.75^{\mathrm{cA}} \pm 0.01$ & $0.58^{\mathrm{dB}} \pm 0$ & $3.32^{\mathrm{cA}} \pm 0.01$ & $3.34^{\mathrm{cA}} \pm 0.03$ \\
$\mathrm{ES}$ & $10.1^{\mathrm{AA}} \pm 0.07$ & $10.30^{\mathrm{aA}} \pm 0.07$ & $1.24^{\mathrm{aA}} \pm 0.01$ & $1.23^{\mathrm{aA}} \pm 0.01$ & $3.56^{\mathrm{aA}} \pm 0$ & $3.45^{\mathrm{bB}} \pm 0.02$ \\
MG & $8.50^{\mathrm{bB}} \pm 0.1$ & $9.90^{\mathrm{aA}} \pm 0$ & $0.89^{\mathrm{bA}} \pm 0$ & $0.77^{\mathrm{cB}} \pm 0$ & $3.33^{\mathrm{cA}} \pm 0.01$ & $3.21^{\mathrm{dB}} \pm 0.02$ \\
\hline
\end{tabular}

Means followed by the same letter in the column and capital in line do not differ by $\mathrm{F}$ and Tukey test at $1 \%$ probability of error.

Table 3. Free $\mathrm{SO}_{2}$ and total $\mathrm{SO}_{2}$ of wines from cv. Isabel produced in different states of Brazil on 2 vintage.

\begin{tabular}{lcccc}
\hline \multirow{3}{*}{ States } & \multicolumn{4}{c}{ Analysis } \\
\cline { 2 - 5 } & \multicolumn{2}{c}{ Free $\mathrm{SO}_{2}\left(\mathrm{mg} \mathrm{L}^{-1}\right)$} & \multicolumn{2}{c}{ Total $\mathrm{SO}_{2}\left(\mathrm{mg} \mathrm{L}^{-1}\right)$} \\
\cline { 2 - 5 } & Vintage 2014 & Vintage 2015 & Vintage 2014 & Vintage 2015 \\
\hline $\mathrm{PE}$ & $20.30^{\mathrm{dB}} \pm 0.2$ & $25.94^{\mathrm{bA}} \pm 0.4$ & $70.31^{\mathrm{bA}} \pm 1$ & $69.46^{\mathrm{aA}} \pm 0.2$ \\
$\mathrm{RS}$ & $31.06^{\mathrm{CA}} \pm 0.4$ & $18.60^{\mathrm{cB}} \pm 0.4$ & $64.34^{\mathrm{cA}} \pm 0.4$ & $64.51^{\mathrm{bA}} \pm 0.4$ \\
ES & $35.84^{\mathrm{bA}} \pm 0$ & $15.18^{\mathrm{dB}} \pm 0.6$ & $83.96^{\mathrm{aA}} \pm 0.4$ & $70.65^{\mathrm{aB}} \pm 0.7$ \\
MG & $38.05^{\mathrm{aB}} \pm 0.4$ & $40.27^{\mathrm{aA}} \pm 0.4$ & $51.37^{\mathrm{dB}} \pm 0.2$ & $57.34^{\mathrm{cA}} \pm 0.4$ \\
\hline
\end{tabular}

Means followed by the same letter in the column and capital in line do not differ by $\mathrm{F}$ and Tukey test at $1 \%$ probability of error.

wine such as weather and those that are linked to winemaking techniques such as sugaring. However, the weather is a determining factor in the outcome of the alcohol content in regions with extremely hot summers and rapid maturation, the grapes synthesis large amounts of sugar reaching high alcohol levels and other regions with less hot summers, the grapes cannot reach high alcohol levels. It can be observed in this study that the Minas Gerais state obtained the highest average for the variable alcohol in two vintage $\left(12.14^{\circ} \mathrm{GL}\right.$ vintage 2014 and $11.96^{\circ} \mathrm{GL}$ vintage 2015), however the RS state presented the lowest average $\left(10.03^{\circ} \mathrm{GL}\right)$. and similar to the values found by Rizzon \& Miele [13] studying the correction of the cv. Isabel grape must in Serra Gaucha (RS state) that showed average values between 9.34 and $10.81^{\circ} \mathrm{GL}$ also to the results found [14] to evaluate Cabernet Franc wines in the state of RS $\left(9.65^{\circ} \mathrm{GL}\right)$.

As for the total dry extract. among the wines analyzed samples of ES state $\left(27.30 \mathrm{~g} \mathrm{~L}^{-1}\right)$ and MG state (28.56 $\mathrm{g} \mathrm{L}^{-1}$ ) had higher averages for the 2014 vintage and 2015 vintage the PE state $\left(28.80 \mathrm{~g} \cdot \mathrm{L}^{-1}\right)$ and MG state $\left(29.36 \mathrm{~g} \mathrm{~L}^{-1}\right)$ showed the highest values (Table 1). De Oliveira [15] found higher values on the dried extract to Cabernet Sauvignon wines of PE state $\left(33.97 \mathrm{~g} \mathrm{~L}^{-1}\right)$, it points out that the perception of "body" is also related to the dry matter content Total wine and this parameter is increased to the amount of sugar added to wine during fermentation [16].

The $\mathrm{pH}$ has a great importance on physic-chemical, biological and sensory wine and may potentiate some defects, and the $\mathrm{pH}$ and titratable acidity the two most important properties in acid fruit juices, especially grape must [16]. The wine produced in MG and RS had the lowest pH 3.33 and 3.32 respectively, and these lower values with the average found by Silva [17] of 3.44 for the state of Minas Gerais and Rizzon et al. [18] of 3.42 for wines with Chardonnay grapes produced in the Serra Gaucha (RS state). The volatile acidity in wine is extremely important, because when present in high concentrations may denote a possible contamination of the drink since this parameter is related to the presence of acetic acid [19]. As for volatile acidity levels, samples ES state vintage $2014\left(1.24 \mathrm{~g} \mathrm{~L}^{-1}\right)$ and $2015\left(1.23 \mathrm{~g} \mathrm{~L}^{-1}\right)$ had higher averages (Table 2), however, none of the samples exceeded the established limit Brazilian law $20 \mathrm{mEq} \mathrm{L}^{-1}$ or $1.2 \mathrm{~g} \mathrm{~L}^{-1}$ acetic acid. The normal volatile acid is 0.6 to $0.7 \mathrm{~g} \mathrm{~L}^{-1}$ in acetic acid [12]. For the total $\mathrm{SO}_{2}$ content, minimum values of $51.37 \mathrm{mg} \mathrm{L}^{-1}$ for the state of $\mathrm{MG}$ in 2014 vintage and maximum $83.96 \mathrm{mg} \mathrm{L}^{-1}$ (Table 3) were observed. All values were below the maximum allowed by law, which is up to $350 \mathrm{mg} \mathrm{L}^{-1}$. As current recommendations, the amount of added $\mathrm{SO}_{2}$ should be reduced due to its allergenic characteristics, or low health quality grape or process vinification leading to rapid consumption of $\mathrm{SO}_{2}$. The use of sulfur dioxide should take into account the health status of grapes, the acidity, whereas in high acidity (low $\mathrm{pH}$ ) the sulfur dioxide efficiency is higher [20].

The Table 4 shows the values for anthocyanins and total polyphenol index, where, for variable anthocyanin, MG state sample stood out in two seasons with the highest average $2530.15 \mathrm{mg} \mathrm{L}^{-1}$ (vintage 2014) and $2960.71 \mathrm{mg} \mathrm{L}^{-1}$ (vintage 2015). Souza [11], studying the oxidative process in American grapes, found similar 
Table 4. Anthocyanins and total polyphenols, from cv. wines Isabel, produced in different states of Brazil on 2 vintage.

\begin{tabular}{|c|c|c|c|c|}
\hline \multirow{3}{*}{ States } & \multicolumn{4}{|c|}{ Analysis } \\
\hline & \multicolumn{2}{|c|}{ Anthocyanin $\left(\mathrm{mg} \mathrm{L}^{-1}\right)$} & \multicolumn{2}{|c|}{ Polyphenol $\left(\mathrm{g} \mathrm{L}^{-1}\right)$} \\
\hline & Vintage 2014 & Vintage 2015 & Vintage 2014 & Vintage 2015 \\
\hline RS & $1757.8^{\mathrm{bB}} \pm 14.32$ & $2470.0^{\mathrm{bA}} \pm 104.07$ & $67.2^{\mathrm{cA}} \pm 0.66$ & $64.46^{\mathrm{CB}} \pm 1.44$ \\
\hline PE & $511.82^{\mathrm{cB}} \pm 16.54$ & $1354.83^{\mathrm{cA}} \pm 39.14$ & $52.6^{\mathrm{dA}} \pm 0.63$ & $47.70^{\mathrm{dB}} \pm 0.57$ \\
\hline ES & $375.44^{\mathrm{dB}} \pm 0.78$ & $502.07^{\mathrm{dA}} \pm 2.75$ & $115.7^{\mathrm{aB}} \pm 0.30$ & $118.5^{\mathrm{aA}} \pm 1.07$ \\
\hline MG & $2530.15^{\mathrm{aB}} \pm 3.43$ & $2960.71^{\mathrm{aA}} \pm 4.14$ & $84.56^{\mathrm{bB}} \pm 0.32$ & $96.8^{\mathrm{bA}} \pm 0.29$ \\
\hline
\end{tabular}

Means followed by the same letter in the column and capital in line do not differ by $\mathrm{F}$ and Tukey test at $1 \%$ probability of error.

Table 5. Color Index and hue (tone) wines from cv. Isabel produced in different states of Brazil on 2 vintage.

\begin{tabular}{|c|c|c|c|c|}
\hline \multirow{3}{*}{ States } & \multicolumn{4}{|c|}{ Analysis } \\
\hline & \multicolumn{2}{|c|}{ Color index } & \multicolumn{2}{|c|}{ Hue } \\
\hline & Vintage 2014 & Vintage 2015 & Vintage 2014 & Vintage 2015 \\
\hline RS & $8.25^{\mathrm{bA}} \pm 0.45$ & $7.76^{\mathrm{bA}} \pm 0.22$ & $7.5^{\mathrm{bA}} \pm 0.41$ & $7.09^{\mathrm{bA}} \pm 0.20$ \\
\hline $\mathrm{PE}$ & $5.97^{\mathrm{cA}} \pm 0.28$ & $6.29^{\mathrm{cA}} \pm 0.21$ & $5.41^{\mathrm{cA}} \pm 0.25$ & $5.68^{\mathrm{cA}} \pm 0.19$ \\
\hline ES & $4.57^{\mathrm{dA}} \pm 0.14$ & $4.81^{\mathrm{dA}} \pm 0.04$ & $4.21^{\mathrm{dA}} \pm 0.12$ & $4.21^{\mathrm{dA}} \pm 0.03$ \\
\hline MG & $13.22^{\mathrm{aB}} \pm 0.02$ & $17.69^{\mathrm{aA}} \pm 0.01$ & $11.88^{\mathrm{aB}} \pm 0.01$ & $15.97^{\mathrm{aA}} \pm 0.01$ \\
\hline
\end{tabular}

Means followed by the same letter in the column and capital in line do not differ by $\mathrm{F}$ and Tukey test at $1 \%$ probability of error.

Table 6. Organic acids determined by high-performance liquid chromatography (HPLC) coupled with DAD cv. Isabel wine samples produced in different regions of Brazil.

\begin{tabular}{|c|c|c|c|c|c|c|}
\hline \multirow{3}{*}{ State } & \multicolumn{6}{|c|}{ Acids $\left(g \cdot L^{-1}\right)$} \\
\hline & \multicolumn{2}{|c|}{ Acetic } & \multicolumn{2}{|c|}{ Citric } & \multicolumn{2}{|c|}{ Lactic } \\
\hline & 2014 & 2015 & 2014 & 2015 & 2014 & 2015 \\
\hline $\mathrm{PE}$ & $308.2 \pm 25.0^{\mathrm{abB}}$ & $402.6 \pm 11.2^{\mathrm{a} A}$ & $270.6 \pm 164.0^{\mathrm{bA}}$ & $195.2 \pm 15.7^{\mathrm{cA}}$ & $3575.3 \pm 88.7^{\mathrm{aB}}$ & $6879.2 \pm 12.1^{\mathrm{aA}}$ \\
\hline RS & $293.0 \pm 22.9^{\mathrm{abA}}$ & $257.26 \pm 22.5^{\mathrm{bA}}$ & $66.6 \pm 3.9^{\mathrm{bB}}$ & $434.33 \pm 41.2^{\mathrm{bA}}$ & $1566.6 \pm 58.4^{\mathrm{bB}}$ & $2061.6 \pm 40.1^{\mathrm{bA}}$ \\
\hline ES & $369.2 \pm 27.1^{\mathrm{aA}}$ & $356.5 \pm 24.9^{\mathrm{aA}}$ & $786.0 \pm 68.1^{\mathrm{aA}}$ & $669.4 \pm 83.7^{\mathrm{aA}}$ & $757.9 \pm 40.3^{\mathrm{dA}}$ & $818.6 \pm 33.4^{\mathrm{cA}}$ \\
\hline \multirow[t]{4}{*}{ MG } & $287.13 \pm 36.0^{\mathrm{bB}}$ & $346.8 \pm 35.0^{\mathrm{aA}}$ & $100.86 \pm 0.67^{\mathrm{bA}}$ & ND & $1405.2 \pm 84.4^{\mathrm{cB}}$ & $2182.1 \pm 25.8^{\mathrm{bA}}$ \\
\hline & \multicolumn{6}{|c|}{ Acids $\left(g \cdot L^{-1}\right)$} \\
\hline & \multicolumn{2}{|c|}{ Malic } & \multicolumn{2}{|c|}{ Succinic } & \multicolumn{2}{|c|}{ Tartaric } \\
\hline & 2014 & 2015 & 2014 & 2015 & 2014 & 2015 \\
\hline $\mathrm{PE}$ & ND & $37.66 \pm 8.4^{\mathrm{bA}}$ & $1360.5 \pm 121.4^{\mathrm{cB}}$ & $1874.0 \pm 52.83^{\mathrm{aA}}$ & $2642.0 \pm 383.0^{\mathrm{bcA}}$ & $2371.4 \pm 236.4^{\mathrm{bA}}$ \\
\hline RS & ND & ND & $835.6 \pm 121.7^{\mathrm{dA}}$ & $619.3 \pm 86.4^{\mathrm{cA}}$ & $3172.7 \pm 100.6^{\mathrm{bB}}$ & $3720.2 \pm 320.3^{\mathrm{aA}}$ \\
\hline ES & $3367.2 \pm 24.8^{\mathrm{aB}}$ & $3223.0 \pm 56.5^{\mathrm{aB}}$ & $1781.0 \pm 107.3^{\mathrm{bA}}$ & $1507.6 \pm 121.9^{\mathrm{abB}}$ & $2319.8 \pm 433.4^{\mathrm{cA}}$ & $2125.1 \pm 336.5^{\mathrm{bA}}$ \\
\hline MG & ND & ND & $2275.3 \pm 248.6^{\mathrm{aA}}$ & $1287.4 \pm 37.1^{\mathrm{bB}}$ & $4736.6 \pm 202.5^{\mathrm{aA}}$ & $3929.2 \pm 49.5^{\mathrm{aB}}$ \\
\hline
\end{tabular}

ND: Not Detected. Means followed by the same letter between states in the same crop and capital to the same state between crops do not differ by $\mathrm{F}$ and Tukey test at $5 \%$ probability of error.

averages ranging from $2748 \mathrm{mg} \mathrm{L}^{-1}$ till $707 \mathrm{mg} \mathrm{L}^{-1}$. The ES state had the lowest averages in relation to anthocyanins 375.44 mg. $\mathrm{L}^{-1}$ (vintage 2014) and $502.07 \mathrm{mg} \mathrm{L}^{-1}$ (vintage 2015), results higher than those found by Sousa [10], which found $150.93 \mathrm{mg} \mathrm{L}^{-1}$ in Isabel wines in ES state. It can be seen that for all samples the anthocyanins values decreased from one harvest to another. Queiroz [21], studying the evolution of Porto wine observed a tendency to decrease the values of all anthocyanins which is generally indicative of the formation of more stable compounds, which originally formed. The total polyphenols index shows a wide variation between the samples of each state and between vintages and the Espírito Santo state presented the highest average 115.7 (vintage 2014) and $118.5 \mathrm{~g} \mathrm{~L}^{-1}$ (vintage 2015). Rizzon et al. [1] evaluated the wine produced with different cultivar Isabel and identified polyphenols in different yields ranging from $13.6 \mathrm{~g} \mathrm{~L}^{-1}$ to $30.4 \mathrm{~g} \mathrm{~L}^{-1}$. These levels were low according to the authors, showing reduced content of these components in grapes, they explain that this variation may be due to the difficulties to control the various factors involved as the genetic characteristics of the grapes, the winery location, soil and climatic conditions, winemaking process, aging. Freitas [22], evaluating the evolution of phenolic compounds in the conservation of red wines of RS state, found that the concentration of total polyphenols ranged between cultivars being Cabernet Sauvignon $2329.8 \mathrm{mg} \mathrm{L}^{-1}$, Merlot $2209.7 \mathrm{mg} \mathrm{L}^{-1}$ and Tannat $1448.8 \mathrm{mg} \mathrm{L}^{-1}$.

In American group of grapes, the anthocyanin is generally connected to two glucose molecules in the form of diglycoside, and these are red pigments responsible for the coloration of red wines [1]. As well as polyphenols, anthocyanins values resulted in differences between vintage and between states (Table 4) and to this variable, the MG state sample obtained the highest average in the vintage of $2014\left(2530.15 \mathrm{mg} \mathrm{L}^{-1}\right)$ and vintage $2015\left(2960.71 \mathrm{mg} \mathrm{L}^{-1}\right)$. Consequently, the color intensity (13.22/17.69 and 2014/2015) and the pitch (11.88/15.97 and 2014/2015) were higher in those samples indicating a greater amount of the natural pigment in wines (Table 5). Rizzon \& Miele [13], evaluating wine from cv. Isabel from Serra Gaucha (RS state), found differences between vintage for anthocyanin variable (from 104.5 to $203.6 \mathrm{mg} \mathrm{L}^{-1}$ ) and consequently also found differences in the intensity of color and hue, the same as when the authors 


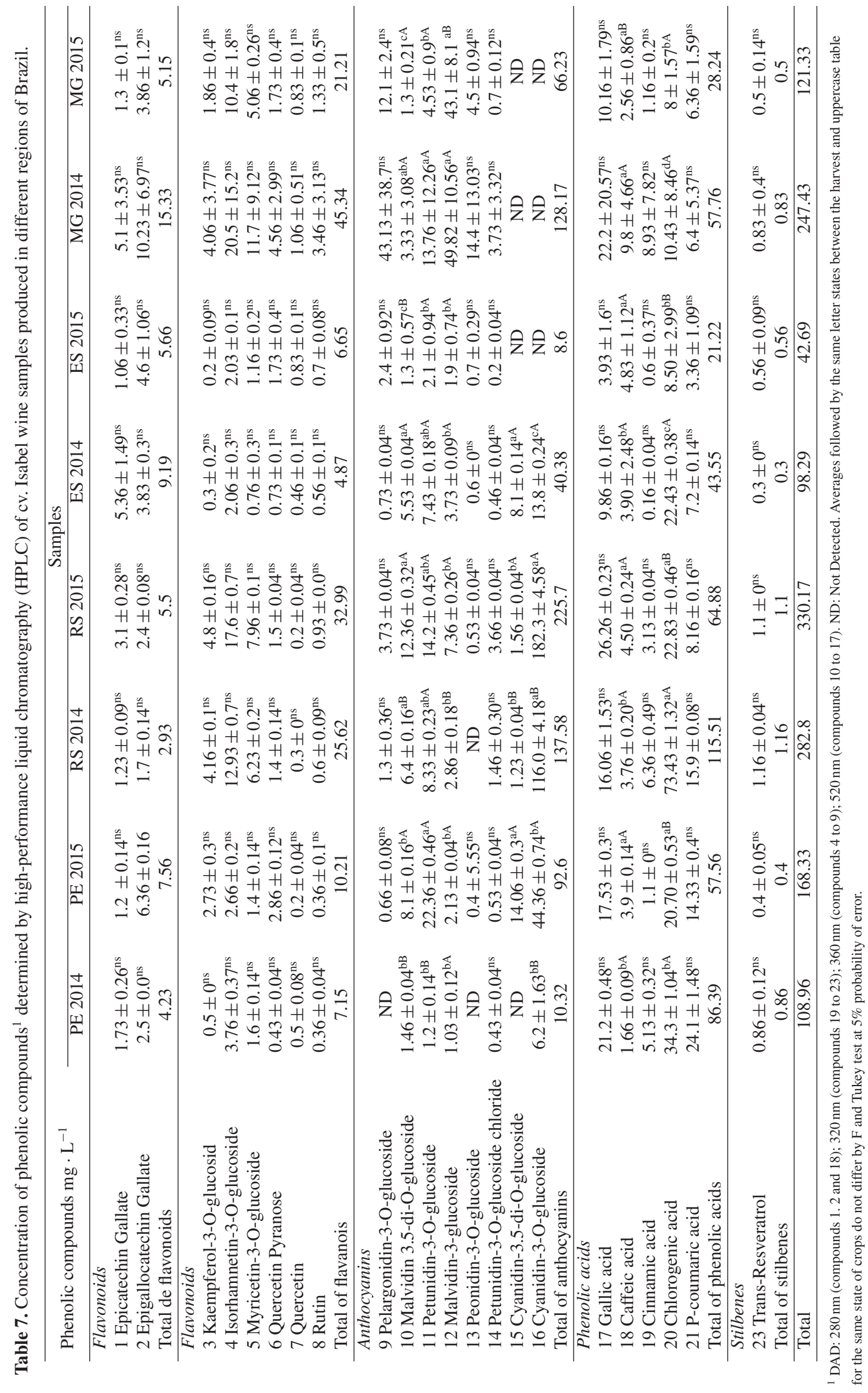


evaluated Cabernet Sauvignon wine anthocyanin found values ranging from $361-430 \mathrm{mg} \mathrm{L}^{-1}$ [14]. Once extracted for wine, anthocyanins, catechins and tannins are gradually converted, including pigmented tannins; these reactions are responsible for color and flavor changes observed during aging wine [23].

The results for the organic acid content of the analyzed wines are shown in Table 6. The principal acids found in the samples were the tartaric and lactic acids, the MG state obtained the highest values of tartaric acid for both vintage $2014\left(4736.6 \mathrm{~g} \mathrm{~L}^{-1}\right)$ as the vintage $2015\left(3929.2 \mathrm{~g} \mathrm{~L}^{-1}\right)$. The ES state had the lowest averages were observed $2319.8 \mathrm{~g} \mathrm{~L}^{-1}$ vintage in 2014 and $2125.1 \mathrm{~g} \mathrm{~L}^{-1}$ in vintage 2015. Related to the lactic acid the highest averages were observed for PE state (3575.3 and $6879.2 \mathrm{~g} \mathrm{~L}^{-1}$ ) and the lowest for the ES state $\left(757.9\right.$ and $818.6 \mathrm{~g} \mathrm{~L}^{-1}$ ) vintage 2014 and 2015 respectively. Malic acid was not detected in samples of Pernambuco vintage 2014. Rio Grande do Sul and Minas Gerais vintage 2014 and 2015. Representing a large part of total acids, the tartaric and malic acids are the two main acids found in grapes, the concentrations of these acids are linked to maturation of grape variety and the manufacturing process [24.25]. Studies by Lima et al. [26], with grape juice showed total amounts of organic acids ranging from 8.64 to $12.04 \mathrm{~g} \mathrm{~L}^{-1}$.

In relation to acetic acid, the values were between $287.13 \mathrm{~g} \mathrm{~L}^{-1}$ (MG) to $369.2 \mathrm{~g} \mathrm{~L}^{-1}$ (ES) for vintage 2014 and $257.13 \mathrm{~g} \mathrm{~L}^{-1}$ to $402.6 \mathrm{~g} \mathrm{~L}^{-1}$ vintage 2015 . The acid acetic is not desirable in high concentrations; it can refer the contamination and a lack of care during handling of raw materials or lack of hygiene during the wine making process [27]. Phenolic acids (especially cinnamic acid) are the main phenolic compounds in grape pulp in juices and wines. Anthocyanins located in the grapes skins. flavonols are constituent of the skins, stems and leaves, as well as catechins and tannins, which are also present in seeds and need to pass through a maceration phase to be, extracted [28].

In relation to total polyphenols (Table 7) found, the values are different for all states, and the Rio Grande do Sul state samples had the highest values (330.17 and $282.6 \mathrm{mg} \mathrm{L}^{-1}$ ), and samples of the Espírito Santo state had the lowest values (42.69 and $\left.98.29 \mathrm{mg} \mathrm{L}^{-1}\right)$. Seruga et al [29], evaluating wines made from Vitis vinifera grapes grown in different geographical region of Croatia, noted variations in the amount of polyphenols to the different places, the same correlated antioxidant activity with high content of polyphenols total, this suggests that the antioxidant activity is derived of different phenolic compounds present in wine.

For trans-stilbene resveratrol samples did not differ significantly, however, the highest value was $1.16 \mathrm{mg} \mathrm{L}^{-1}$ in the sample of the Rio Grande do Sul state. Nixdorf and Gutiérrez [30], studying wine cultivar Isabel found values for oxidizing activity between 2.5 to $6.25 \mathrm{mmol} \mathrm{L}^{-1}$ and rated a low value in the medium compared with other red wines, where values ranging from 1.2 to $25.5 \mathrm{mmol} \mathrm{L}^{-1}$. Souto et al. [31] analyzed 36 samples of wines produced in the south region of Brazil and found that resveratrol concentrations ranged from 0.82 to $5.43 \mathrm{mg} \mathrm{L}^{-1}$. Lucena et al. [32] evaluated different wines and found values of $0.69 \mathrm{mg} \mathrm{L}^{-1}$ for wine Syrah, $0.04 \mathrm{mg} \mathrm{L}^{-1}$ to grow Cabernet Sauvignon and $1.26 \mathrm{mg} \mathrm{L}^{-1}$ for Merlot. According to Goldberg et al. [33], resveratrol synthesized by vine has higher concentrations in the berry skin, being extracted and transferred to the wine during fermentation and maceration processes, the low levels can be explained by the time of fermentation and maceration during the winemaking.

Regarding the anthocyanins, the Rio Grande do Sul state obtained the highest total values for the two analyzed vintage $\left(137.58\right.$ and $\left.225.7 \mathrm{mg} \mathrm{L}^{-1}\right)$ being the cyanidin-3-O-glucoside compound was the anthocyanin presented the highest value $116.0 \mathrm{mg} \mathrm{L}^{-1}$ vintage 2014 and $182.3 \mathrm{mg} \mathrm{L}^{-1}$ vintage 2015 . To the compound malvidin3-O-glucoside, the Minas Gerais state stood out and found $49.83 \mathrm{mg} \mathrm{L}^{-1}$ for vintage 2014 and $43.1 \mathrm{mg} \mathrm{L}^{-1}$ for vintage 2015 (Table 7). Nixdorf and Gutiérrez [30] found total anthocyanins values for Isabel cultivar wines from 149.76 to $212.78 \mathrm{mg} \mathrm{L}^{-1}$ to the Rio Grande do Sul state and from 14.41 to $2.65 \mathrm{mg} \mathrm{L}^{-1}$ for Parana state. Castilhos et al. [34], studied the influence of the pre-drying under the phenolic compounds in wine made from grapes of BRS Carmen and Bordô, and found that the total number of anthocyanins varies in accordance with procedures for the production of wine when compared the traditional procedure with pre-drying found that the BRS Carmen ranged from 301.2 to $199.6 \mathrm{mg} \mathrm{L}^{-1}$, and wine from $\mathrm{cv}$. Bordô 415 to $273.5 \mathrm{mg} \mathrm{L}^{-1}$.

Quercentin, the more common flavonol in the grapes, abundant in the leaves and is also present in the skin and stems. Its concentration may be increased in the grape berries exposing them to sunlight. Catechin and quercetin can increase the color stability of new wines and also have antioxidant properties similar to resveratrol [23]. The groups of phenolic compounds flavonols and flavanols showed no significant differences in any treatment (Table 7). Ruiz-García et al. [35], studying wines produced from grapes cultivar L. Monastrell (Vitis vinifera) in 2009 and 2010 in Spain, identified a total of anthocyanin $431.5 \mathrm{mg} \mathrm{L}^{-1}$ for the year 2009 and $257.5 \mathrm{mg} \mathrm{L}^{-1}$ to 2010 in relation to flavonols identified whose the values were $54.5 \mathrm{mg} \mathrm{L}^{-1}$ (2009), $51.7 \mathrm{mg} \mathrm{L}^{-1}$ (2010). The authors report that this difference occurred because the precipitation was higher in 2010 which could have reduced the concentration of phenolics in the skin.

\section{Conclusion}

It is concluded that the wines produced from the cv. Isabel in the Espírito Santo state, have physicochemical characteristics very close to those of the wines produced in other table wine-producing regions of Brazil.

The wine showed physic-chemical differences between the crops in the same region, probably due to extrinsic factors to the winemaking process.

\section{References}

[1] L. A. Rizzon, A. Miele, J. Meneguso, Cienc. e Tec. Alim, 20 (2000)

[2] F. M, Tecchio, A. Miele, L.A. Rizzon, Cienc. Rural, 37 (2007)

[3] U. A. Camargo, Cong. Lat. Am. Vit. En, 195-199 (2005)

[4] Brasil, Inst. Norm., DOU 24, (1988)

[5] O.I.V, Vine and Wine Outlook 2006-2012 18, (2012) 
[6] V. Cheynier, M. Moutounet, P. Sarni-Manchado, Enologia: Fundamentos científicos y tecnológicos, 783p. (2000)

[7] M.M.P. Natividade, L.C. Corrêa, S.V.C. Souza, L.C.O. Lima, Microch. J, Microch. J, 110 (2013)

[8] A.C.P. Rybka, E.G. Pereira, A.C.T. Biasoto, L.C. Corrêa, Livro de resumo, http://iufost. org.br/sites/iufost.org.br/files/anais/ 05609.pdf

[9] F.A.S. Silva, Assistat Prog. Anal. Est, http:// assistat.com/indexp.htlml

[10] M.I.L. Souza, U.F.V, Tese (2014)

[11] L.A. Rizzon, Embrapa (2010)

[12] Brasil, Lei $n 7.678$ nov. 1988 DOU, (2005), http://www.planalto.gov.br/ccivil_03/leis/ 1980-1988/L7678.htm

[13] L.A. Rizzon, A. Miele, Cienc. Tec. Alim. 20 (2002)

[14] L. Manfroi, A. Miele, L.A. Rizzon, C.I.N. Barradas, Cienc. Tec. Alim. 26 (2006)

[15] L.C. De Oliveira, S.O. De Souza, M.E.O. Mamede, Rev. Inst. Adolfo Lutz, 70 (2011)

[16] B.T. Onsi, Inst. Fed. Ed. Cienc. Tec. (2010)

[17] T.G. Silva, M.A. Regina, J.P. Rosier, L.A. Rizzon, N.N.J. Chalfun, Cienc. Agrot. 23 (1999)

[18] L.A. Rizzon, A. Miele, G. Scopel, Cienc. Rural, 39 (2009)

[19] B.A.C. Santos, Unicamp, Tese (2006)

[20] M.R. Sobrinho, Unicamp, Tese (2013)

[21] M.J.G. Queiroz, Univ. do Porto, Tese (2015)

[22] D.M. Freitas, Univ. Fed. S. Maria, Tese (2000)
[23] J. Robinson, The Oxford Comp. to Wine, (2006)

[24] H.F. Liu, B.H. Wu, P.G. Fan, S.H. Li, L.S. Li, J. Sc. Food and Ag, 86 (2006)

[25] T.P. Ribeiro, M.A.C. Lima, R.E. Alves, Pesq. Agrop. Bras. 47 (2012)

[26] L.A.A. Lima, Univ. Fed. Pern., Tese (2010)

[27] K.M.F. Ali, Y. Choi, R. Verpote, Phytoch. Reviews, 9 (2010)

[28] C.R. Malacrida, S. Motta, Rev. Cienc. Tec. Al., 26 (2005)

[29] M. Seruga, I. Novak, L. Jakobek, Food Chem. 124 (2011)

[30] S.L. Nixdorf, I. Hermosín-Gutiérrez, Analyt. Chim. Acta, 659 (2010)

[31] A. Souto, M.C. Carneiro, M. Seferin, M.J.H Senna, A. Conz, K. Gobbi, J. Food Comp. Analys. 14 (2001)

[32] A.P.S. Lucena, R.J.B. Nascimento, J.A.C. Maciel, J.X. Tavares, J.M. Barbosa-Filho, E.J. Oliveira, J. Food Comp. Analysis, 23 (2010)

[33] D.M. Goldberg, J. Yan, E.P. Diamandis, A Karumanchiri, G. Soleas, A.L. Waterhouse, Am. J. Enol. Vit, 46 (1995)

[34] M.B.M. De Castilhos, O.L.D. Correa, M.C. Zanus, J.D.G. Maia, S. Gomez-Alonso, E. Garcia-Romero, V.L. Del Bianchi, I. Hermosin-Gutierrez, Food R. Int. 76 (2015)

[35] Y. Ruiz-Garcia, I, Romero-Casales, R. Gil-Muñoz, J.I. Fernández-Fernández, J.M. Lópz-Roca, E. Gómez-Plaza, J. Agr. Food Chem. 60 (2012) 